\title{
HEALTH MANAGEMENT: THE USE OF INFORMATION SYSTEMS AND KNOWLEDGE SHARING FOR THE DECISION MAKING PROCESS ${ }^{1}$
}

\author{
Alba Lúcia Santos Pinheiro², Kerlly Taynara Santos Andrade ${ }^{3}$, Dejeane de Oliveira Silva4, Fabiana Costa \\ Machado Zacharias, ${ }^{5}$ Mariana Figueiredo Souza Gomide ${ }^{6}$, Ione Carvalho Pinto ${ }^{7}$
}

\footnotetext{
${ }^{1}$ Paper extracted from the dissertation - The use of information systems as a tool for health management decision making in cities in the South of the State of Bahia, presented to the Programa de Pós-Graduação em Enfermagem, Escola de Enfermagem de Ribeirão Preto (EERP), Universidade de São Paulo (USP), in 2014. Call 005/2009 Ação Novas Fronteiras of CAPES/MEC.

${ }^{2}$ Ph.D. in Sciences. Professor, Departamento Ciências da Saúde (DCS), Universidade Estadual de Santa Cruz (UESC). Ilhéus, Bahia, Brazil. E-mail: albapinheiro@usp.br

${ }^{3}$ Undergraduate Nursing student. UESC. Scientific Initiation Scholarship student, Fundação de Amparo à Pesquisa do Estado da Bahia. Ilhéus, Bahia, Brazil. E-mail: ktsandrade@hotmail.com

${ }^{4}$ Doctoral student in Nursing. Escola de Enfermagem, Universidade Federal Bahia. Professor at DCS/UESC. Ilhéus, Bahia, Brazil. E-mail: dejeanebarros@yahoo.com.br

${ }^{5}$ M.Sc. in Sciences. Ribeirão Preto, São Paulo, Brazil. E-mail: fabianazacharias@hotmail.com

${ }^{6}$ Doctoral student, Programa de Pós-Graduação em Enfermagem, EERP/USP. Ribeirão Preto, São Paulo, Brazil. E-mail: mariana.souza@ usp.br

7 Ph.D. in Nursing. Professor, Departamento de Enfermagem Materno-Infantil e Saúde Pública, EERP/USP. Ribeirão Preto, São Paulo, Brazil. E-mail: ionecarv@eerp.usp.br
}

\begin{abstract}
This study aimed to analyze the use of Health Information Systems in the decision-making process by the management from cities located in Southern Bahia, Brazil. A qualitative approach was employed; subjects were 16 secretaries of health. Data were collected through interviews and subject to the content analysis technique; Knowledge Management was used as the theoretical framework. The managers are still beginners in the use of Health Information Systems; several actors are involved in the decision; there is low qualification in Health Information Systems; managements implement innovation, even if incipiently; difficulties happen when a new system is established and because of internet access. It was concluded that Health Information Systems' use to support knowledge production has not reached yet its full potential; it is suggested that management should promote the strengthening of the information culture and should seek to construct knowledge based on the expertise of different actors for the decision.
\end{abstract}

DESCRIPTORS: Information systems. Health management. Decision-making. Knowledge management.

\section{GESTÃO DA SAÚDE: O USO DOS SISTEMAS DE INFORMAÇÃO E O COMPARTILHAMENTO DE CONHECIMENTO PARA A TOMADA DE DECISÃO}

RESUMO: Estudo teve como objetivo analisar o uso dos Sistemas de Informação em Saúde no processo de tomada de decisão pela gestão em municípios do sul da Bahia, Brasil. Utilizou-se abordagem qualitativa, os sujeitos foram 16 secretários de saúde. Dados coletados através de entrevista e submetidos à técnica de análise de conteúdo; adotou-se o referencial da Gestão do Conhecimento. Os gestores ainda são neófitos no uso dos Sistemas de Informação em Saúde; há envolvimento de atores na decisão, porém em alguns casos não há efetiva participação social; ocorre pouca qualificação em Sistema de Informação em Saúde; gestões implementam inovação, embora incipiente; há dificuldade quando da implantação de sistema novo e acesso à Internet. Conclui-se que a utilização dos Sistemas de Informação em Saúde como substrato para a produção do conhecimento ainda não atinge todo o seu potencial, sugere-se que a gestão promova o fortalecimento de uma cultura informacional e busque construir um conhecimento inscrito em saberes de distintos atores para a decisão.

DESCRITORES: Sistemas de informação. Gestão em saúde. Tomada de decisões. Gestão do conhecimento. 


\section{GESTÓN DE LA SALUD: EL USO DE LOS SISTEMAS DE INFORMACIÓN Y EL COMPARTIR DE CONOCIMIENTO PARA LA TOMA DE DECISIÓN}

RESUMEN: El estudio tuvo como objetivo analizar el uso de los Sistemas de Información en Salud en el proceso de toma de decisión por la gestión en municipios del sur de Bahia, Brasil. Se utilizó aproximación cualitativa. Los sujetos fueron 16 secretarios de salud. Datos recolectados a través de entrevista, sometidos a la técnica de análisis de contenido y el referencial de Gestión del Conocimiento. Los gestores aún son principiantes en el uso de los Sistemas de Información en Salud, hay implicación de actores en la decisión, sin embargo en algunos casos no hay efectiva participación social; ocurre poca calificación en Sistemas de Información en Salud; gestión implementan innovación, aunque incipiente; hay dificultad cuando de la implantación de sistema nuevo y acceso a la internet. Se concluye que la utilización de los Sistemas de Información en Salud como sustrato para la producción del conocimiento aún no alcanza todo su potencial, sugiere que la gestión promueva el fortalecimiento de una cultura informacional y construye un conocimiento inscrito en saberes de distinguidos actores para la decisión.

DESCRIPTORES: Sistemas de información. Gestión en salud. Toma de decisiones. Gestión del conocimiento.

\section{INTRODUCTION}

The management of the Unified Health System (SUS) is a process through which managers (subjects) make decisions on the implementation of the Health Policy. ${ }^{1}$ The databases and Health Information Systems (HIS) are important tools for the planning and assessment of health policies, services, networks and systems. ${ }^{2}$

In Brazil, different federal HIS were established even before the implementation of the SUS and its objectives were focused on the federal and/ or state governments. The cities took on the role of data collectors and, frequently, the information was underused. Thus, they remained distanced from the elaboration process of planning, with little or no experience/autonomy for the formulation of policies and for decision making. ${ }^{3}$

Based on the SUS Basic Operating Standard from 1996 (NOB/SUS 01/96), the cities' responsibility in the assumption of their decision-making role in the actions within their territory. To comply with this new role, the need increased to produce readily available information to support the professionals and managers' work. ${ }^{3}$ In that sense, the Ministry of Health implemented different HIS and their use is compulsory in all states and cities.

The information provides a new viewpoint to interpret events or phenomena, which grants visibility and formerly invisible meanings. Thus, the information is a means or material needed to extract and construct the knowledge. ${ }^{4}$ In contrast, the data can be characterized as a property of things. Knowledge is a property of agents, predisposing them to act in certain circumstances. ${ }^{5}$

The theoretical-conceptual reference framework of Knowledge Management (KM) was used in this study, as it adds value to the object and, at the same time, supports the anchoring of discussions on the theme addressed. KM is an integrated set of actions to identify, capture, manage and share all of an organization's information assets. This information can take the form of a database, printed documents and other media, articulating people, contents and communication with a view to organizing the institution's expertise for decision making. It is based on shared learning, cooperation and knowledge sharing and involves not only the production of information, but also the communication of information based on or deriving from the analysis of the data for the people who need to work with them. ${ }^{4,6-7}$

In addition, a historical age of unprecedented technological development is ongoing, which makes the current society be acknowledged as the society of knowledge and technology. ${ }^{8}$ Knowledge has been considered one of the most important resources of an organization, as it can make actions more intelligent, efficient and effective, at the organizational and individual levels. That stimulates the elaboration of innovative and excellent products and services. ${ }^{9}$

Hence, the objective in this study was to analyze the use of HIS in the decision making process by the health management from cities in the South of Bahia, Brazil.

\section{METHOD}

A qualitative study was undertaken in the State of Bahia, which consists of 417 cities, distributed across 28 health regions. The South of the state includes four regions. The study was developed in 16 cities in the South of Bahia, with the city of Itabuna as the main city.

In the organizational structure of a Health Department, generally, the Municipal Health Secretaries are nominated as commissioned posts and, frequently, they are health professionals. The criterion to include participants in the study was to exercise the function/post of municipal health manager (secretary) in one of the 21 cities in the health region Itabuna. 
After applying the inclusion criteria, in total, 16 managers continued. The semistructured interview was used as the data collection technique, undertaken between September 2013 and May 2014. Participants unwilling to grant an interview after three appointment attempts were eliminated.

Among the 16 participants, nine had worked as municipal health secretaries in the same or in other cities; five had already worked as co-managers in health, that is, they had worked with the secretary through shared responsibilities and decisions at the central level of the Health Department, performing actions related to the practice of planning, elaboration of projects, supervision, assessment, monitoring, among others. Only two had no background management experience. Among the 16 participants, ten were nurses.

To analyze the data, the content analysis technique was chosen, using the theme as the registration unit. Empirical categories were built that were modified in the course of the analysis, in a dynamic process of constant confrontation between experience and theory. Finally, they originated one main theme that led to three subthemes.

This study was developed in compliance with National Health Council Resolution 466 from December/2012. The project was submitted to the Research Ethics Committee of the University of São Paulo at Ribeirão Preto College of Nursing and approval was obtained in accordance with the Ethical Evaluation Certificate (CAAE) 12431113.0.0000.5393 from April/2013.

To guarantee the participants' anonymity, Arabic numerals were used to indicate the order of participation in the data collection, that is, Manager 1 (G1), Manager 2 (G2), Manager 3 (G3) and so forth.

\section{RESULTS AND DISCUSSION}

\section{Theme - Management Practices: their dialogues with the HIS and the use of knowledge for decision making}

\section{Subtheme - The managers' look on themselves, on the production of information and the involvement of distinct actors in the decision}

With their different agendas and in view of the complexity of the area, the health managers have been confronted in their daily life with different challenges, including the use of information as fundamental resources to develop knowledge for decision making.
The following excerpts signal that there are managers who acknowledge their limitations and do not use the full potential of the HIS.

About the HIS, no, I'm not using everything, because it's a lot to use, because there's a lot to be done (G5).

What we use of the HIS is still very little. [...] I always say that it's a tool in our favor, but we still do not know how to properly use it. We still don't use everything they offer (G2).

The information is expected to function as a tool to guide decision making and the production of valid knowledge. Different kinds of information and from different sources would serve as the paramount substrate of these processes. ${ }^{2}$

The following excerpts demonstrate different actors' involvement and participation in decision making.

Most decisions are in accordance with the needs of the moment, because there's a lot of popular participation, not only through the councils, there's a community radio where people discuss a lot, we see the needs, many active councilors and entities, we close agreements with evangelical churches, partnerships, the community participates a lot (G12).

[...] the Municipal Health Council is very participative. They were even invited to a meeting of the regional councils next week and our Municipal Health Council was chosen to present the success of the council when it is participative and active. [...] many decisions we also await the council's decision, even if it is not compulsory (G1).

The information and decision model in health needs to be reconsidered to value the different dimensions of the human being, as well as through a complementary health information and informatics policy that grants appropriate support to the decision process. In addition, the best ways for the managers to apprehend the information need to be discussed with a view to strategic decisions. ${ }^{10}$

Not the knowledge and judgments constitute the decision, but support it, mainly by displacing current thinking. In addition, the knowledge should depart from the daily it intends to explain, a hybrid of local knowledge and significantly constructed by the network of stakeholders involved in these problems. ${ }^{2}$

On the opposite, there are other managers who appoint the legal role of the Municipal Health Council (MHC), only used to approve projects.

Look, to be sincere, what the Municipal Health Council is concerned, we take the decisions made here at the secretary for this council to approve, so that's how it happens. Normally, we don't discuss these things first, 
unfortunately it's like that. These decisions are not taken in group (G15).

The council serves more to implant programs. [...] when we implanted it, we had to ask for the Council's approval, so generally we use it for that end, for approval (G11).

The legal role of the MHC demonstrated in the study is marked by a harsh reality that goes against the guidelines and defense of the SUS, as the institutional channels of participation, as a space for decision and negotiation, should be guaranteed. Thus, a concrete health management agenda is needed which triggers processes that encourage social participation. Empowerment based on health information for critical appropriation by the different actors is essential to construct knowledge and, consequently, to formulate strategies to cope with the problems and guide decision making.

In the broad context of information and knowledge management, the creation of intelligent groups is fundamental, which permits collaborative competency building in the different professional categories involved in the information and knowledge. The intelligent groups are at the same type dynamic and potential spaces, considering that knowing is qualitatively superior to gaining information but, at the same time, the latter is the base of the former. ${ }^{11}$

Health management still rests on traditional methods and strategies. Therefore, the construction of new forms of managing the area, based on participation and interdisciplinary practices, where workers and users act as active subjects, remains a challenge. ${ }^{12}$

In a study developed at a regional health district in the Federal District, the managers reported the belief that the team and the users want a sensitive manager when a problem emerges, who knows how to listen to those around him. The manager does not act alone: he needs support from the multiprofessional team to achieve the objectives. ${ }^{13}$

Different managers confirm that they discuss with their co-management team to make a decision:

[...] in case of epidemiological surveillance issues, for example, I already make the decision together with the epidemiological surveillance coordinator, I use the coordinators, of basic care and other coordinators we have in the city. Those are the people who truly help me to make decisions (G15).

So we use practically all of our directors here, the planning director, but all other sectors depending on the sector of the demand, we use them all, health surveillance, medium and high complexity, primary care (G14).
Decision making is a responsibility and competency of the manager who, besides the information obtained, uses his personal knowledge (technical, political, institutional, social, cultural references, among others) and his perception of the problem, establishes a conviction and makes a decision, mobilizing the resources needed. ${ }^{14}$

Some managers explain that a differential in their management for decision making is their accumulated experience. That confirms their profile, as only two have no management experience.

[...] experience is a factor that helps anyone, due to the fact that I have occupied the secretary in some periods, it's the fourth time I get back to the secretary. So that provides some more skills, although each mandate are different times, but it grants some tranquility (G2).

I think I have some qualities, first the experience of already having occupied several posts in the three governmental spheres (G14).

The knowledge refers to the beliefs and commitments that occur in function of a specific attitude, perspective or intention, and is therefore related to the action in a given context. ${ }^{4}$ The set of data can even provoke different response of different people. At different times, the same set of data reviewed by the same person could result in decision making with different reactions or actions. ${ }^{5}$

The knowledge can take on different shapes based on distinct viewpoints of the stakeholders from different perspectives and interests.

One important frailty the managers assume is the lack of or the small number of qualifications to use the HIS, although some have been qualified when they worked as professionals.

I had to learn in daily work, in practice. I actually learned in the system, looking, asking, the typists. I think the main problems in health itself are the qualifications, it leaves to be desired (G12).

I participated in training in HIS when I worked at the consulting service, I used to participate a lot in this training [...] what we don't know how to do we can't charge (G6).

Look, what has been difficult in this program thus far, which was implanted, the e-SUS. [...] the main difficulty is because there has been no training yet [...] (G10).

No, I have never been qualified as a manger, only when I was a nurse in the Family Health Strategy (FHS), I knew everything about the SIAB [Primary Care Information System] (G8).

In a study developed in small cities in the state of Rio Grande do Sul, it was evidenced that many 
cities emphasized the need for staff qualification and team training to analyze the collected data and insert them in the systems. ${ }^{3}$

In another study involving SUS managers, one of the main weaknesses highlighted was the professionals' lack of preparation for administrative tasks and the slow incorporation of new information technologies. In Brazil, the culture still prevails that any professional knows how to manage and that administration is learned in practice. ${ }^{12}$

Nursing is the only health profession whose undergraduate curriculum includes the subject administration, involving practical activities. ${ }^{12}$ The largest part of the sample in our study consisted of nurses. Therefore, these subjects can be expected to have at least some proximity with the theoretical and practical sphere of administration.

Capacity building on information use is expected to effectively take place in the local context on a larger scale (specializations, qualifications), developing skills to master techniques and technologies, but also strengthening competencies locally with a view to the creative and innovative use of the information. ${ }^{2}$

The excerpts below demonstrate that two realities exist: managers who perceive the importance of the HIS and who envisage the potential of these systems, and others who understand that the data analysis should happen based on other management spheres:

It is very important, the use of the HIS, among different factors, what I find most important is how fast you seek the information for you to make the necessary decisions (G14).

I find the use very important [...]. This information system is good to know the city's situation, the rate, whether some target was achieved or not. Therefore, it's very important when the Ministry of Health and the State of Bahia Health Department (SESAB) publish these data on their website, that makes our work much easier to have some guidance, a broad view of the health reality (G11).

In practice, it is very common that, although people understand and learn new knowledge, they still hesitate to use if for a variety of reasons. People will resist any innovation that can oblige them to give up their alleged comfort zone, that is, to abdicate from what they believe in in favor of what is new. The resistance to change is powerful, despite objective evidence that a certain change makes sense. ${ }^{15}$

Some secretaries affirm that they delegate the actions of dealing with the HIS to the typists:
Because, generally, in a small city we never have time, so I let the responsible for all systems, a boy who has worked with me for many years (G10).

[...] These systems need to be more simplified and the technicians involved in this information aspect need training, the technicians from the Data Processing Central. I would not even include the manager, because the manager is in a general context (G15).

Although the informational competency is a specific competency related to the skill to cope with information, it is not restricted to the information professionals. ${ }^{11}$

\section{Subtheme 2 - Daily health management: deployments and possibilities for the use of the HIS}

Despite some obstacles for the use of the HIS by management and social control, knowledge production based on information can represent a dialogical bridge between the health policies, planning and grounded decision making, due to the possibility to materialize the constitutional principles of equity and integrality in effective actions in the daily practice of the SUS.

One interviewee referred to the large number of HIS present in management: [...] it's like this, there are many programs to feed, so I think that, from my point of view it could be limited to one or two, three HIS (G11).

There is a wide range of information and knowledge, which makes it a challenging task to capture, store, recover and use in the public sector. ${ }^{16}$ The large data volume can be a friend of data management, but it is an enemy of knowledge management, simply because the volume needs to be filtered to find the desired knowledge. ${ }^{17}$ The sustainable advantage an organization has is what it truly knows, its efficiency to use what it knows and how readily it gains and uses new knowledge. ${ }^{6}$

The following highlights appoint that some cities have tried to implement innovation, even if incipiently, in order to facilitate the management practices.

[...] we created a worksheet to deal with the material entry and exit control, with the warehousing. We are implanting a system that is more complex but, through Excel, which is nevertheless an information system to try and solve things (G3).

Now I hired a company [...] What is the company going to do? You type the SIAB at the unit and it is interconnected in the network (G12).

I urgently need to be able to guarantee the hiring of aperson graduated in communication to help me with the 
publicity of these data, not for propaganda, but to involve the community in the management (G3).

The secretaries highlight that there is a deficit in the structure and, in some resources, for the HIS to be able to function appropriately.

We have few computers, few typists, few people working in the system, you see? So this system could be serving us better, if there were a structure (G14).

Today, we are trying to improve the part of informatics in the city, I think we will be able to improve when all units, mainly the nurses, had the best access. Today, there are some units in the city with a computer and the internet, but I want all of them to work [...] (G6).

The lack of computers was appointed as a problem for the use of the HIS for only $10 \%$ of the research participants, ${ }^{3}$ which possibly indicates greater facility in the access to informatics inputs. In that reality, the Internet access, in turn, was disseminated but weak. This result reveals an inequality between the reality of the cities in the South and Northeast of Brazil.

\section{Subtheme 3 - The relevance of the information technologies applied to health management}

Knowledge Management is much more than technology, it is the effective and efficient use of technology as a part of the Knowledge Management system. The use of modern information and communication technologies (ICTs) permits the collection, systemization, structuring, storage, combination, distribution and provision of valuable information. ${ }^{17}$

The databases of the HIS take shape as explicit knowledge that can turn into tacit (subjective) knowledge. Thus, the knowledge can be considered a two-way route that can migrate from tacit to explicit and vice versa. ${ }^{17}$

Even today, with the different existing innovations to publish data in on-line local databases (Departamento de Informática do Sistema Único de Saúde - DATASUS - and websites of State Health Departments, Automatic Data Recovering System - SIDRA - of the Instituto Brasileiro de Geografia e Estatística - IBGE -, among others), the demands of the managers and users of all governmental spheres are not completely answered, in terms of planning, monitoring, evaluation, among others. ${ }^{2}$

The managers affirmed that different HIS are used in their daily practice, among which they highlighted the SIAB, the Monitoring System of Works (SISMOB).

Generally I use the monthly report of the SIAB (G10).
I use the SIS-MOB a lot. I am responsible for the part of the construction register of units, reforms, expansions (G13).

On the occasion of the data collection, the cities studies went through a transition from the SIAB to the new Primary Health Care Information System (SISAB). That change was done through the software e-SUS AB, conceived by the Primary Care Department of the Ministry of Health, with a view to improving the quality and guaranteeing more detailed information. Thus, the goal is to integrate different existing information systems in primary care, among other improvements. It is highlighted that the participating managers expected and at the same time felt apprehension, which is frequent in the implantation of a new system.

Some managers signal the difficulty when a new system is implanted.

Last year, there was an orientation to start to do the immunization SI-PNI of the web system, [...] a new system, in the region no city had implanted it and if we could serve as a pilot. We did this proposition that we were willing. Some time later, in the system, our vaccination index was almost zero. Due to a problem in the system, we would almost be impaired, we were about to close to agreement of the indicators and almost all vaccines were down to zero percent (G1).

I expect the e-SUS to work, but it will depend on several factors to work. First, the e-SUS will consider several of these systems. So, it's something we have always dreamt of, because it reduces that thing of role, bureaucracy. I hope it will work. But I have already felt kind of disappointed by the staff of the SESAB, responsible for the e-SUS [...] there is still a lot of doubt, that is the main problem (G12).

One of the obstacles the cities face is the internet access, as the HIS need to forwarded to other spheres, new versions need to be downloaded, and some HIS are typed online. The interview fragments highlight that.

[...] we buy notebooks for rural areas, and then the nurse establishes connections with other places, she brings the notebook and forwards the data. In the rural areas there's no internet, broadband has not arrived here (G16).

The fact of not being computerized, health is not in a network so that makes it difficult, for example, does the FHS have access? No, it doesn't. To have this access you need to come here at the health center to use the computer, which may become somewhat easier now, because computers will be installed to the units, for the telehealth system as well as the immunization system 
that will need to be computerized. So we think that will already be an advance (G2).

[...] We have a lot of difficulty, starting with internet access, it doesn't work on broadband here, the Internet is slow. So this difficulty is striking across the region, mainly in interior cities (G15).

Our difficulty here is the Internet. The Internet here is slow [...] (G9).

The Federal Government, through the National Broadband Program at Primary Health Care Units (UBS), intends to take broadband Internet to the UBS in the cities. That will result in greater quality and speedy care, guarantee and safety in the HIS data transmission process, real-time access to information and knowledge. ${ }^{18}$

Different obstacles are found for the effective use of the HIS: lack of standardization of health data collection and treatment procedures; difficulty to link the health services with broadband Internet; insufficient funding strategies in information and informatics; deficient professional qualification in this theme, among others. In that context, the Federal Executive power had to formulate a new policy to try and remedy these gaps in the management of the SUS. ${ }^{19}$

The managers appointed the indicators they commonly use based on the HIS and some decisions to be made.

Vaccination campaign, you need to see the vaccination coverage target, we talk to each agent: how many children do you have in your micro-area? He will list who these children area, then you need to do the active search, who will still do this vaccine? (G5).

The SINAN [Information System of Notification of Diseases], which is the reporting, we saw that we had an exorbitant number of reports of sexually transmitted diseases. When we started working more intensely on Sexually Transmitted Diseases, working more in schools and in the community with educative activities, the rate dropped (G1).

Differently from the results of our study, in a study undertaken, ${ }^{3}$ the use of the HIS to construct indicators the managers value was low, and less than $5 \%$ of the municipal secretaries were fully satisfied with the information the HIS provided.

Overall, gross data are presented, without producing statistical data and information that, in combination, can produce evidences for local decision making. They do not serve either to further the construction processes of meaning for the decisions and for the interventions needed. To give an example, although the IBGE Demographic Census considers micro-areas in its census sectors, which often correspond to the same micro-areas defined by the FHS, the team of professionals and even the municipal manager ignores them (either because the team does not know it or due to a total lack of integration between the data). ${ }^{2}$

Some managers call attention to the possibility of (un)reliable data some systems offer:

Depending on the information system, some are reliable, while others [...]. It is one of our claims here that the coordination is always assessing these data to make them as true as possible, close to reality (G6).

If the typist wants to make the changes upward or downward, he needs to have all of this power at hand. I think that can be the unreliability. [...], because he can say: 'no, that is very bad, we want to reach this target here', he can make that change. The person needs to be highly responsible, to work on information systems you need committed people (G7).

Weak HIS are constant challenges for all management spheres, as the performance of the health systems cannot be properly assessed or monitored when the data are incomplete, imprecise or unsuitable. $^{20}$

It is hard for the ICTs by themselves to create the knowledge or guarantee its production. They can nevertheless favor the agility and information dissemination, mainly in the field of health production, where knowledge itself is a public good and, the more it is shared, the more its power tends to increase.

In the Brazilian public administration, Knowledge Management is being implemented to maximize citizenship, social wellbeing, transparency, for the efficacious application of public resources, among others. Thus, Knowledge Management, being cross-sectional, is in line with the guidelines of the SUS, as it favors the visibility of the information, enhancing participation and social control. ${ }^{7}$

Thus, Knowledge Management will add value to other existing tools, contributing to overcome the challenges health management is confronted with.

\section{FINAL CONSIDERATIONS}

The study highlighted that the use of the HIS has not reached its full potential yet, as health management uses it incipiently for the decision process. In general, they use and share data and information, but the challenges are perceived that need to be faced in the use of the information as a substrate for the production of knowledge and decisions. 
In the study context, two contradictory realities take shape: in one, different actors are involved and there is popular participation in decision making. In the other, the legal role of the health council is presented, only used for the approval of projects. In this context, the management needs to involve the different subjects in the use and sharing of knowledge. The actual participation, mainly of the councils, in the decisions adds contributions and views according to each context and reality, promotes a representative process of dialogue in a legitimate and inclusive manner.

The relevance of the HIS was emphasized. The systems are considered tools for planning, for decision making and for overall health management. Nevertheless, one important weakness that was noteworthy in the study was the small number of qualifications to use the HIS and Internet access difficulties. Despite obstacles, some managers have tried to implement innovation, although incipiently, to facilitate the sharing of information and improve the management practices.

This research made no claim on creating/ constructing a specific knowledge management model for health management, but intends to provide clues that can be deepened in other studies. Knowledge management was discussed in the study as a theoretical contribution to enlighten the decision process.

There exists no formula that makes the health managers use the HIS for decision making. Nevertheless, the management should promote the strengthening of an informational culture at the municipal health departments and encourage an organizational environment that consolidates the use of the information to construct knowledge and share it to support the decision process. It is not about a linear and regulatory logic. Therefore, this study offers elements to reflect on and discuss possibilities, on other ways to conduct the use of the HIS to construct management that engages in the improvement of the SUS.

\section{REFERENCES}

1. Tamaki EM, Tanaka OY, Felisberto E, Alves CKA, Drumond Junior M, Bezerra LCA, et al. Metodologia de construção de um painel de indicadores para o monitoramento e a avaliação da gestão do SUS. Cienc Saude Colet [Internet]. 2012 [cited 2014 Dec 30]; 17(4):. Available from: http://www.scielo.br/pdf/csc/ v17n4/v17n4a07.pdf

2. Ferla AA, Cecim RB, Alba RD. Information, education and health care work: Beyond evidence, collective intelligence. RECIIS - Rev Eletr Com Inf Inov Saude [Internet]. 2012 Ago [cited 2014 Oct 03]; 6(2): http:/ / www.reciis.icict.fiocruz.br/index.php/reciis/article/ view/477/pdf_303,Sup.

3. 3.Vidor AC, Fisher PD, Bordin R. Utilização dos sistemas de informação em saúde em municípios gaúchos de pequeno porte. Rev Saúde Pública [Internet]. 2011 [cited 2014 Oct 03]; 45(1):24-30. Available from: http://dx.doi.org/10.1590/S003489102011000100003

4. Nonaka I, Takeuchi H. Criação de conhecimento na empresa. $7^{\mathrm{a}}$ ed. Rio de Janeiro (RJ): Campus; 1997.

5. United Nations Public Administration Network (UNPAN). Featured Learning Materials, Gestão do Conhecimento na Organização Governamental. Sessão II - Gestão do Conhecimento em Organizações Governamentais e Programas, 2014. [cited 2014 Aug 30]. Available from: http://workspace.unpan.org/ sites/Internet/Documents/UNPAN93043.pdf

6. Davenport TH, Prusak L. Working knowledge: how organizations manage what they know. Boston: Harvard Business School, 1998.

7. Molina J. Not missing the train of history! Rev Esc Enferm USP [Internet]. 2014 Fev; [cited 2015 May 15]; 48 (1). Available from: http://dx.doi.org/10.1590/ S0080-623420140000100001

8. Lorenzetti J, Trindade LL, Pires DEP, Ramos FRS. Technology, technological innovation and health: a necessary reflection. Texto Contexto Enferm [Internet]. 2012 Abr-Jun [cited 2014 Oct 21]; 21(2):432-9. Available from: http://www.scielo.br/scielo.php?script=sci_ arttext\&pid=S0104-07072012000200023\&lng=en\&nr $\mathrm{m}=\mathrm{iso} \& \mathrm{tlng}=\mathrm{en}$

9. Rocha ESB, Nagliate P, Furlan CEB, Kerson Rocha Jr, Trevizan MA, Mendes IAC. Gestão do conhecimento na saúde: revisão sistemática de literatura. Rev Latinoam Enfermagem [Internet]. 2012 [cited 2014 Oct 21]; 20(2):[09 telas]. Available from: http://www.scielo. br/pdf/rlae/v20n2/pt_24.pdf

10. Cavalcante RB, Kerr MMP. Política Nacional de Informação e Informática em Saúde: avanços e limites atuais. Perspectivas em Gestão \& Conhecimento 2011; 1:106-19.

11. Souza ED, Dias EJW, Nassif ME. A gestão da informação e do conhecimento na ciência da informação: perspectivas teóricas e práticas organizacionais. Inf \& Soc: Est [Internet]. 2011 [cited 2013 Feb 3]; 21(1):55-70. Available from: http://www.ies.ufpb.br/ojs2/index. php/ies/a rticle/view/4039/5598

12. Lorenzetti J, Lanzoni G, Assuiti LF, Pires DE, Ramos FR. Health management in Brazil: dialogue with public and private managers. Texto Contexto Enferm [Internet]. 2014 [cited 2014 Aug 30]; 23(2):417-25. Available from: http://www.scielo.br/scielo.php?script=sci_ arttext\&pid=S0104-07072014000200417\&lng=en\&nr $\mathrm{m}=\mathrm{iso \& t} \operatorname{lng}=\mathrm{en}$

13. Silva M, Rodrigues V, Alves E. Gestão dos serviços 
de saúde no Sistema Único de Saúde (SUS) em uma regional de saúde do Distrito Federal (SES-DF): uma visão do gestor relacionada ao preparo para a função. Gestão e Saúde. 2013 Set; 4(3):843-60.

14. Tanaka, OY, Tamaki, EM. O papel da avaliação para a tomada de decisão na gestão de serviços de saúde. Cienc Saude Colet. 2012; 17(4):821-8.

15. United Nations Public Administration Network (UNPAN). Featured Learning Materials, Gestão do Conhecimento na Organização Governamental. Sessão III - Processo de Gestão do Conhecimento: perspectivas Centradas na Linha de Pessoas e no Conhecimento; 2014. [cited 2014 Aug 30]. Available from: http://workspace.unpan.org/sites/Internet/ Documents/UNPAN93044.pdf

16. Misra DC. Ten Guiding Principles for Knowledge Management in E-government in Developing Countries. In: First International Conference on Knowledge Management for Productivity and Competitiveness, 2007 Jan 11-12; New Delhi (IN): National Productivity Council; 2007.
17. United Nations Public Administration Network (UNPAN). Featured Learning Materials, Gestão do Conhecimento na Organização Governamental. Sessão V - Foco em Tecnologia da Informação aplicada à Gestão do Conhecimento e Tecnologias para a Gestão do Conhecimento nas Organizações Governamentais; 2014 [cited 2014 Aug 30]. Available from: http:// workspace.unpan.org/sites/Internet/ Documents/UNPAN93046.pdf

18. Ministério da Saúde (BR). Diretoria de Atenção Básica. Plano Nacional de Banda Larga [Internet]. 2014 [cited 2014 Dec 28]. Available from: http:/ / dab.saude.gov. $\mathrm{br} /$ portaldab/esus.php?conteudo=conectividade

19. Ministério da Saúde (BR). Política de Informação e Informática em Saúde. Brasília (DF): Comitê de Informação e Informática em Saúde; 2012.

20. Mutale W, Chintu N, Amoroso C, AwoonorWilliams K, Phillips J, Baynes, et al. Improving health information systems for decision making across five sub-Saharan African countries: Implementation strategies from the African Health Initiative. BMC Health Services Research. 2013; 13 Suppl 2: 1-12.
Correspondence: Alba Lúcia Santos Pinheiro

Universidade Estadual de Santa Cruz, Departamento Ciências da Saúde

Rodovia Jorge Amado, Km 16

45.662-900 - Salobrinho, Ilhéus, BA, Brasil

E-mail albapinheiro@usp.br
Received: July 15, 2015

Approved: November 27, 2015 